УДК 78.03+782.1

DOI https://doi.org/10.31723/2524-0447-2019-29-2-22

\author{
Ду Вей \\ ORCID: 0000-0003-3399-4278
}

здобувач кафедри історії музики та музичної етнографії

Одеської національної музичної академії імені А. В. Нежданової

WeiduOd19@gmail.com

\title{
СПЕЦИФІЧНІ ВЛАСТИВОСТІ \\ ВОКАЛЬНОГО ІНТОНУВАННЯ \\ В ОПЕРНОМУ МИСТЕЦТВІ: ДО ПРОБЛЕМИ ЕМОЦІЙНО-КОГНІТИВНОГО ЗМІСТУ МУЗИКИ
}

Метою статті є дослідження феномена вокального інтонування та розгляд його впливу на оперне мистеитво. Відзначається, що в ході історичного розвитку оперного мистецтва розроблявся та постійно продовжував свій розвиток інтонаційно-смисловий лад музичної вокальної драматургії з основною опорою на можливості людського голосу, на виразний комплекс мовних інтонацій. Явище вокального інтонування $\epsilon$ одним із найдавніших способів передачі емоційно-смислового змісту світу через звучання мови й музики, визначає головні сенсоутворювальні інтенції та комунікативні функції такого музично-культурного явища. Через глибинне проникнення в самий трунт музикальності, інтонування здатне виражати сутність сприйняття людиною навколишнього світу й взаємини з ним, невербально виразити сенс речей та явищ. Методологія роботи визначається єдністю історико-культурологічного, літературознавчого, психологічного, музикознавчого аналітичного й оперознавчого підходів, що формує цілісний міждисииплінарний грунт дослідження. Наукова новизна полягає в тому, що суть інтонації розкривається як один із прадавніх $і$ найприродніших способів передачі емоційного, смислового й семантичного вмісту навколишнього світу за допомогою звучання мови, музики, іншими словами, як головний смислоутворювальний і комунікативний параметр культурного феномену.

Висновки. У вокальному інтонуванні узагальнюються та репрезентуються емоційно-психологічні стани, особистісний та узагальнений досвід переживання, що дозволяє безпосередньо виявляти емоційно-когнітивний зміст музики. Вокальне інтонування набуває нових якостей і деякої автономії від вербального тексту, надаючи останньому особливу умовність y безпосередньому звучанні оперного твору. Серед важливих якостей вокального інтонування в контексті оперного мистецтва слід наголосити на широкій просторовості й тяжінні до наскрізного музичного розвитку, що є наслідком специфічного сценічного звукового розгортання оперної діï.

Ключові слова: оперне мистецтво, музична інтонація, вокальне інтонування, емоційно-смислова складова частина вокальної інтонації, музично-сиенічна інтерпретація оперного твору. 
Du Wei, Applicant at the Department of Music History and Musical Ethnography of the Odessa National A. V. Nezhdanova Academy of Music

Specific features of vocal intonation in opera: on the problem of the emotional and cognitive content of music

The purpose of the article is to investigate the phenomenon of vocal intonation and consider its influence on operatic art. It is noted that in the course of the historical development of opera, the intonation-semantic structure of musical vocal drama was developed and constantly continued its development, with the main reliance on the capabilities of the human voice, on the expressive complex of speech intonations. The phenomenon of vocal intonation is one of the most ancient ways of transmitting the emotionalsemantic content of the world through the sounds of speech and music, it determines the main meaning-generating intentions and communicative functions of this musical-cultural phenomenon. Through a deep penetration into the very soil of musicality, intonation is capable of expressing the essence of a person's perception of the world around him and his relationship with him, not verbally expressing the meaning of things and phenomena. The methodology of the work is determined by the unity of the historical, cultural, literary, psychological, musicological, analytical and operaological approaches, forms a holistic interdisciplinary basis of the research. The scientific novelty lies in the fact that the essence of intonation is revealed as one of the oldest and most natural ways of conveying the emotional, semantic and semantic content of the surrounding world through the sound of speech, music, that is, as the main semantic and communicative parameter of a cultural phenomenon.

Conclusions. In vocal intonation, emotional and psychological states, personal and generalized experience are generalized and presented, which makes it possible to identify the emotional and cognitive content of music. Vocal intonation acquires new qualities and some autonomy from the verbal text, providing the latter with a special convention in the direct sounding of an opera work. Among the important qualities of vocal intonation in the context of operatic art, one should point out a wide spatiality and a gravitation towards cross-cutting musical development, which is a consequence of the specific stage sound development of an operatic action.

Key words: opera art, musical intonation, vocal intonation, emotional and semantic component of vocal intonation, musical and stage interpretation of an opera work.

Ду Вей, соискатель кафедры истории музыки и музыкальной этнографии Одесской национальной музыкальной академии имени А. В. Неждановой

Специфические особенности вокального интонирования в оперном искусстве: к проблеме эмоционально-когнитивного содержсания музыки

Целью статьи является исследование феномена вокального интонирования и рассмотрения его влияния на оперное искусство. Отмечается, что в ходе исторического развития оперного искусства разрабатывался и постоянно продолжкал свое развитие интонационно-смысловой строй музыкальной вокальной драматургии с основной опорой на возможности человеческого голоса, на выразительный комплекс речевых интонаций. Явление вокального интонирования является одним древнейших способов передачи эмоционально-смыслового содержания мира через звучания речи и музыки, определяет главные смыслопорождающие интенции и коммуникативные функции такого музыкально-культурного 
явления. Через глубинное проникновение в самую почву музыкальности интонирование способно выражать сущность восприятия человеком окружающего мира и взаимоотношения с ним, не вербально выразить смысл вещей и явлений. Методология работы определяется единством историко-культурологического, литературоведческого, психологического, музыковедческого аналитического и опероведческого подходов, формирует целостную междисциплинарную основу исследования. Научная новизна заключается в том, что суть интонации раскрывается как один из древнейших и самых естественных способов передачи эмоционального, смыслового и семантического содержания окружающего мира с помощью звучания речи, музыки, то есть как главный смыслообразующий и коммуникативный параметр культурного феномена.

Выводы. В вокальном интонировании обобщаются и представляются эмоционально-психологические состояния, личностный и обобщенный опыт переживания, что позволяет выявлять эмоционально-когнитивное содержание музыки. Вокальное интонирование приобретает новые качества и некоторую автономию от вербального текста, предоставляя последнему особую условность в непосредственном звучании оперного произведения. Среди важных качеств вокального интонирования в контексте оперного искусства следует указать широкую пространственность и тяготение к сквозному музыкальному развитию, что является следствием специфического сиенического звукового развертывания оперного действия.

Ключевые слова: оперное искусство, музыкальная интонация, вокальное интонирование, эмоционально-смысловая составляющая вокальной интонации, музыкально-сценическая интерпретация оперного произведения.

Актуальність теми дослідження. У багатьох дослідженнях, присвячених вивченню опери, однією з найважливіших властивостей називають синтетичність іiі жанрової природи, що втілювалась різними театральними й сценічними засобами. Поруч із тим, у процесі еволюції оперного жанру саме особливий тип вокального інтонування як музично інтонуємого слова стає головною ознакою такого жанрового напряму. Характерологічність і специфічність вокального інтонування в оперному мистецтві полягає в обов'язковому взаємозв'язку 3 настановами видатних вокальних шкіл і музично-мовних принципів, які існували під час створення оперного твору.

Явище вокального інтонування $є$ одним із найдавніших способів передачі емоційно-смислового змісту світу через звучання мови й музики, визначає головні сенсоутворювальні інтенції та комунікативні функції такого музично-культурного явища. Через глибинне проникнення в самий грунт музикальності інтонування здатне виражати сутність сприйняття людиною навколишнього світу й взаємини з ним, не 
вербально виразити сенс речей та явищ. Історичний путь оперного жанру красномовно свідчить про безпосередній зв'язок іiі поетики 3 необхідністю комунікативної передачі й демонстрування емоційної складової частини людського спілкування, що закладає підгрунтя для формування мовних принципів такої комунікації.

Музичну складову частину можна назвати визначальною для оперного жанру, бо без перебільшень можна стверджувати, що такий жанр із самого початку свого існування вибудовує нову систему музично-мовних принципів, які за своїми емоційно-психологічними параметрами переважають мову вербальну й навіть пов'язані зі словом літературно-поетичні форми.

Метою статті є дослідження феномена вокального інтонування та розгляду його впливу на оперне мистецтво. Відзначається, що в ході історичного розвитку оперного мистецтва розроблявся та постійно продовжував свій розвиток інтонаційно-смисловий лад музичної вокальної драматургії з основною опорою на можливості людського голосу, на виразний комплекс мовних інтонацій. Методологія роботи визначається єдністю історико-культурологічного, літературознавчого, психологічного, музикознавчого аналітичного й оперознавчого підходів, що формує цілісний міждисциплінарний грунт дослідження. Наукова новизна полягає в тому, що суть інтонації розкривається як один із прадавніх і найприродніших способів передачі емоційного, смислового й семантичного вмісту навколишнього світу за допомогою звучання мови, музики, іншими словами, як головний смислоутворювальний і комунікативний смисл культурного феномену.

Виклад основного матеріалу. Явище музичної інтонації, як свідчать музикознавчі дослідження Б. Асаф'єва, В. Холопової, В. Медушевського, має безпосередній зв'язок із мовною інтонацією та співвідноситься із словом «тон» як позначенням музичного звуку [10]. Одним із перших дослідників, що виявив зв'язок музичної інтонації із звучанням мови, був Л. Сабанєєв, який у 1923 р. випустив роботу «Музика мови», де музика мови, за його думкою, $є$ «звуковим буттям мови без відношення до ії символіки образів та ідей» [8, с. 15]. Він стверджував, що в музичне буття слова входить насамперед вся звукова структурність слова й мови, весь світ звукових ритмів поезії та художнього слова взагалі, вся милозвучність 
мови - звукова евфонія, вся гра тембрів, звукової динаміки, акцентуації та метричних зв'язків. Сюди входить вся чисто звукова емоційність (експресія, виразність) мови» [8, с. 15].

У роботах Б. Асаф'єва музична інтонація зіставляється з вербально-мовними явищами (мови, речі, слова) й має загальну смислову підставу з емоційно-виразною інтонацією словесної мови. Він визначає інтонацію у своїй роботі «Музична форма як процес» як «явище або «стан тонової напруги», що зумовлює і «мову словесну», й «мову музичну» [2, с. 355].

В. Медушевський, розробляючи теорію інтонації, обгрунтовує ідеї про функціональну асиметрію півкуль головного мозку, де під час складної їх взаємодії в сприйнятті й розумінні музики вирішальну роль відіграє права півкуля. Таке твердження спирається на дослідження в області нейропсихології. «Музична інтонація сприймається як жива тому, що в ній відбита жива людина < ..> Внутрішній світ музики розкривається таємно від вербального, «лівополушарного» мислення [6, с. 184].

Медушевський виділяє цілісність музичної інтонації як iii найважливішу, провідну властивість. Інтонація не розкладається на елементи, а психологічно-емоційне сприйняття музики не передбачає розділення чутної музики на складові частини - мелодику, ритміку, інтерваліку, бо таке усвідомлення музики можливе лише через аналітичні операції, для здійснення яких необхідне спеціальне навчання [6]. Таким чином, взаємозв’язок двох і більше музикальних звуків утворює музичну інтонацію, але поряд із підношенням певної звуковисотності, тембрової забарвленості, динамічної складової частини й так далі інтонація несе яскраве емоційне наповнення, завдяки якому стає можливим формування художнього образу. Саме ці якості музичної інтонації дають можливість розуміти музику на рівні емоційно-смислового переживання.

Запропоноване В. Медушевським поняття про генералізовану інтонацію можна розглядати як узагальнення досліджень у сфері цілісності впливу й сприйняття музичного твору. Він вказує, що генералізована інтонація стає вираженням цілісності музичного твору, що сприймається через чуттєве сприйняття виконавця та слухача.

У роботі $\Theta$. Назайкинського «Звуковий світ музики. Нарис другий. Голос» предметом розгляду стає безпосередньо голос і його невіддільна складова частина - вокальна інтонація. 
Назайкинський вказує, що, слухаючи мову, а тим більше спів, людський слух головним чином чує тембр голосу, його забарвлення, інтонацію, але поряд із цим слух уловлює і емоційну складову частину співу [7]. Зв'язок мовної та вокальної інтонації є надзвичайно важливим не тільки для вокального виконавства, але також для розуміння інструментальної, оркестрової, симфонічної музики. У мові звуки є носіями безлічі сенсів, оскільки вони є елементами фонетичної системи мови й одночасно матеріалом для формування слів та частками звукозображального іряду.

Фонація розуміється як сукупна активність органів мови, що забезпечує як співецький, так і мовний спосіб звуковидобування. Під «співецьким» і «мовним» способом звуковидобування з фізіологічного боку розуміються режими роботи голосового апарату. Безпосереднім способом звуковидобування деякі дослідники, наприклад, О. Іготті, пропонують розділяти на фонаційний (за участю голосового апарату) й нефонаційний (без участі голосового апарату, тобто «звучащі жести») [4]. Як вказує дослідниця, «при фонаційному способі можна виділити звуки, що мають переважаючу частоту основного тону, й звуки, що не мають переважаючої частоти тону. На грунті, з одного боку, рівноправного, а з іншого боку, взаємодоповнювального існування та використання співецького й мовного способів фонаційного звукоутворювання, а також впровадження нефонаційних способів звукодобування виникають нові системи організації вертикалі й горизонталі» [4, с. 4-5].

На процес інтонації робить величезний вплив також і сама особа, яка інтонує. У процесі розвитку особи формуються індивідуальні форми знакової інтонації, такі, як «психомоторний комплекс: індивідуальна пластика й почерк; палітра голосової інтонації: тембр, регістр, швидкість, енергія та наповненість голосу, індивідуальні архетипічні інтонеми»; спрямованість до спілкування в соінтонуванній та «до контрастної чи контрапунктичної інтонації або до припинення повідомлень» [9, с. 145-146]. Складність і багаторівневість індивідуальної інтонаційної форми особи складається завдяки «його генетиці й родовим формам інтонації, етнічним стереотипам і соціальним умовам, особливостям організму, соціокультурного середовища й внутрішнього світу особи» [9, с. 146]. Індивідуальне інтонування має три рівня проявлення. 
Перший - тілесний рівень (або «організмічеський» по Тороповой). До нього належать таки види, як пластика рухів, інтонації голосу, готовність до «соінтонування». В інтонаційних знаках міститься інформація про стать, вік, стан здоров'я та інші, іноді неусвідомлені установки, скриті наміри, які відбиті в пам'яті завдяки особистому досвіду й актуальним потребам організму. Особливо такі інтонаційні знаки проявляються в професійно залежній від тілесної складової частини сфері, а саме в музикальній і театрально-пластичній діяльності. Мова інтонування - це мова афектів, які накопичуються в пам'яті й може мимоволі проявлятися при подібних стимулах, визиваючи повторний афект, змушуючи організм відповідати на них певними інтонаційними еманаціями, що проявиться в рухах чи голосі. Це підтверджує те, що наша пам'ять зберігає певні інтонаційні комплекси й те, що у нас є внутрішнє «Я», яке ми не демонструємо назовні, й це внутрішнє «Я» має свою власну волю, яка не підконтрольна усвідомлюваному «Я». «Весь організм людини «мислить» таємно від нашого інтелекту (таємно для нас), передбачаючи багато що в собі самому й попереджая нас часто від небезпеки, що загрожує нам.<..> Шифр внутрішніх відчуттів ще не прочитаний. $<\ldots>$ дух заважає тілу, тіло - духу», зазначає у своїй роботі «Імагинатівний абсолют» Я. Голосовкер [3, с. 158].

Другий рівень проявлення інтонування - соціальний рівень. «Музика, іiі інтонаційні знаки й форми звернені до соціального контексту, виросли, як показано етологами й антропологами, з комунікативних поведінкових актів і забезпечують особистості «вхід» у соціальний простір» [9, с. 148]. Вміння використовувати певні музичні інтонації при спілкуванні, а також розпізнавати їх, є специфікою спільноти або кола, відкритого для тих, що володіють такими спеціальними кодовими інтонаціями. Цей рівень дозволяє усвідомити свою приналежність до певної культури, етносу, до певного соціального шару.

Третій - це духовно-особистісний рівень, який виявляється в інтонаційному діалозі із самим собою, з надособистісними силами й із Богом. Інакше кажучи, коли ми в думках звернені до Абсолюту або занурені в медитативне самоспоглядання, створюється певний простір за допомогою інтонаційно-мовних кодів, що приєднують нас шляхом особової молитовної інтонації з вищими інтонаційними шарами. «<...> Як немовля 
інтонаційно сповіщає своє народження в реальність, так той, що молиться, знаходить єднальну нитку з тим, до кого звернений, через акт особистісно інтонованої молитви» [9, с. 148].

Інтонація є одним із найпотужніших засобів емоційно-психологічної дії на людей. Виразна сила інтонації активно використовувалася людьми задовго до виникнення музики як мистецтва й, можливо, мови як засобу спілкування. Можливо, тому традиційними релігійними обрядовими культурами способи інтонації строго регламентуються та їх принципам приділяється особлива увага. Своєю чергою домінівними компонентами вокальної мови є співецький і мовний способи звуковидобування, саме такі способи звуковидобування формують базис для утворення різних прийомів вокальної інтонації.

Взаємозумовленість мовної та вокальної інтонації здатна передати всю палітру переживань, емоційних і психологічних станів героя музично-сценічного твору. В оперному мистецтві саме завдяки вокальному інтонуванню можливе розкриття індивідуальності кожного сценічного образу, передача унікальних властивостей і характерологічних особливостей характеру й темпераменту, якими наділив їх автор літературного джерела й композитор. 3 зіткнення різних інтонаційних комплексів вишиковується система стосунків між дійовими особами оперного спектаклю, конфлікт і взаємодія різних сил драматичного ходу подій, народжується «інтонаційна драматургія» опери як музично-драматургічного цілого» [5, с. 20]. Водночас важливою складовою частиною успіху втілення композиторського задуму залишається акторська обдарованість виконавця.

Б. Асаф’єв у своїй роботі «Опера» вказував, що неможливо уявити оперу без вокальної мелодії, «бо в неї, образно виражаючись, «відлітає душа», й жоден симфонічно розвинений, пишний і драматичний чуйний оперний оркестр при всіх своїх правах на еволюцію не може собою замінити безпосередню, беззастережну чарівність людського голосу» [1, с. 64]. Саме людський голос здатний виражати емоції персонажів драми й втілювати їх у вокальній інтонації, але, на думку Б. Асаф’єва, без «інтонаційно осмисленої вокальної речитації, в якій через різні стильові відтінки - від побутового говору й майже розмовної манери до величавого й пристрасного риторського підйому - виражають себе характери дійових осіб, - опера теж немислима, оскільки з неї вилучається гнучка виразна якість: 
жива мова в іiі музичній природі як засіб розкриття драматичного вмісту й сюжетної лінії» [1, с. 64].

Отже, в оперному мелосі виникає свого роду «горизонтальна полістилістика» або горизонтальне вирівнювання та антитетичность контрастних стилістичних комплексів, що слугує виявленню «психологічної поліфонії» провідних оперних образів. Водночас оперна мелодія не тільки не спрощує драматичне напруження та емоційно-психологічне навантаження оперного персонажа, але й виконує функції їх роз'яснення та всебічного демонстрування. «Музичне звучання бере на себе функції поетичного узагальнення, звільненого від семантичного регламенту слова, що веде до зростання ролі симфонічного боку опери. 3 іншого боку, мелодійний музичний матеріал сприяє підвищеній поетизації образу дійової особи, передбачаючи й протилежну можливість - рух в сторону прозового зниження в разі панування словесно-мовного матеріалу, речитативних інтонацій, аж до напівговору або «сухої» мови» $[11$, с. 158].

Структурно-семантичні властивості вокального інтонування $є$ підгрунтям для формування оперної мелодії та вираження інтонаційного змісту музичного тексту опери та його виконавського втілення. Найвагомішими параметрами й визначальними факторами на шляху виявлення головних чинників інтонаційного змісту музичного тексту опери є інтонаційна точність у безпосередній співвіднесеності з виразністю вербального рівня оперного тексту; темброва забарвленість вокального інтонування в діалозі з динамічними й агогічними параметрами, які мають великий вплив на організацію музичного часу твору й підсилюють сприйняття сюжетних колізій та емоційно-психологічних проявів персонажів опери. Через вокальну інтонацію оперне мистецтво отримує можливість встановлювати перший контакт зі слухачем і проникати в його свідомість і підсвідомість. Це стає можливим за допомогою емпатійного співчуття та емоційного співпереживання, яке виникає у процесі художньої комунікації та забезпечує емоційну силу художнього переконання.

Висновки. У вокальному інтонуванні узагальнюються та репрезентуються емоційно-психологічні стани, особистісний та узагальнений досвід переживання, що дозволяє безпосередньо виявляти емоційно-когнітивний зміст музики. Вокальне інтонування набуває нових якостей і деякої авто- 
номії від вербального тексту, надаючи останньому особливу умовність у безпосередньому звучанні оперного твору. Серед важливих якостей вокального інтонування в контексті оперного мистецтва слід вказати широку просторовість і тяжіння до наскрізного музичного розвитку, що є наслідком специфічного сценічного звукового розгортання оперної дії.

Життєздатність і зажадалість оперного мистецтва визначається тим, що воно народилося та продовжує розвиватися на пересіченні різних видів мистецтва з можливістю вкраплення всіляких стилістичних елементів, властивих іншим жанрам. У сучасному світі під оперою треба розуміти широку область музично-сценічних новацій, які деколи виходять далеко за рамки музичного театру, але однією з головних ознак стає той інтонаційно-характерологічний комплекс, що в різних художньо-естетичних, історичних і національних умовах зберігає свою унікальність. Філософсько-естетичні погляди сучасності, нові концептуальні рішення, техніка музичного письма - все це приводить до значних змін оперного жанру. Опера як дуже гнучка синтетична модель вбирає в себе нові форми й види не тільки з різних галузей музичного мистецтва, а звертається в пошуку нових художніх прийомів для втілення емоційно-когнітивного змісту твору до кінематографічного, телевізійного мистецтва, що знаходяться на межі з масовою популярною культурою, що провокує народження нових гібридних форм. Означені вище вимоги сьогодення, з одного боку, й пластичність і мінливість жанрової форми опери - з іншого, могли б привести до нівелювання головних жанрових ознак опери, про що неодноразово вже йшлося, коли обговорювалися питання кризисного стану такої жанрової сфери й лунали голоси, що передрікали «смерть» опери. Разом із тим одним із важливих факторів, які не дають таким негативним тенденціям розвинутися, стає вокальне інтонування (в межах оперного мистецтва) як самодостатній художній феномен, що поряд із функціонуванням стійкого канону й академічних традицій забезпечує можливість подальшого розвитку оперного жанра.

\section{СПИСОК ЛІТЕРАТУРИ}

1. Асафьев Б. Избранные труды. Т. V. Москва : Издательство Академии наук СССР, 1957. 388 с.

2. Асафьев Б. Музыкальная форма как процесс. Кн.1 - 2 / вступ. ст. Е. Орловой. Ленинград : Музыка, 1971. 376 с. 
3. Голосовкер Я. Логика мифа. Имагинативный абсолют. Москва, 1987. 187 с.

4. Иготти Е. Теория и практика интонирования в современной вокальной музыке : дисс. ...канд. искусств. : 17.00.02 «Музыкальное искусство». Санкт-Петербург, 2011. 170 с.

5. Келдыш Ю. Опера. Музыкальная энииклопедия : в 6-ти томах. Москва : Советская энциклопедия, 1978. Т.4. 504 с.

6. Медушевский В. Двойственность музыкальной формы и восприятие музыки. Москва, 1976. 356 с.

7. Назайкинский Е. Звуковой мир музыки. Москва : Музыка, 1988. 254 c.

8. Сабанеев Л. Музыка речи. Эстетическое исследование. Москва : Работник просвещения, 1923. 201 с.

9. Торопова А. Феномен интонирования как знаковая функция. Журнал Развитие личности. Теории и исследования. Личность в контексте культуры. 2012. № 1. С. 136-151.

10. Холопова В. Теория музыки: мелодика, ритмика, фактура, тематизм. Санкт-Петербург : Лань, 2002. 368 с.

11. Чжен Цзин. Тема любви как эстетическая и музыкально-интонационная парадигма оперного жанра : дисс.... канд. искусств. : 17.00.03 «Музыкальное искусство». Одесса, 2013. 167 с.

\section{REFERENCES}

1. Asafiev, B. (1957) Selected Works. T. V. M.: Publishing house of the Academy of Sciences of the USSR. [in Russian].

2. Asafiev, B. (1971) Musical form as a process. Iss. 1- 2. L.: Muzyka. [in Russian].

3. Golosovker, J. (1987) The logic of myth. Imaginative absolute. M. [in Russian].

4. Igotti, E. (2011) Theory and practice of intonation in modern vocal music: dis. ... PhD: 17.00.02 - musical art. SPb. [in Russian].

5. Keldysh, Yu. (1978) Opera. Musical encyclopedia. In 6 vol. M.: Soviet encyclopedia. Vol.4. [in Russian].

6. Medushevsky, V. (1976) Duality of musical form and music perception. M. [in Russian].

7. Nazaikinsky, E. (1988) The sound world of music. Moscow: Music. [in Russian].

8. Sabaneev, L. (1923) Music of speech. Aesthetic research. Moscow: Worker of education. [in Russian].

9. Toropova, A. (2012) Phenomenon of intonation as a sign function. Personal Development Journal. Theory and research. Personality in the context of culture. No. 1. S. 136-151. [in Russian].

10. Kholopova, V. (2002) Music theory: melody, rhythm, texture, thematic. Saint Petersburg: Lan. [in Russian].

11. Zheng Jing. (2013) The theme of love as an aesthetic and musicalintonational paradigm of the opera genre / Diss.... Cand. arts .; special .: 17.00.03 - musical art. Odessa. [in Russian]. 